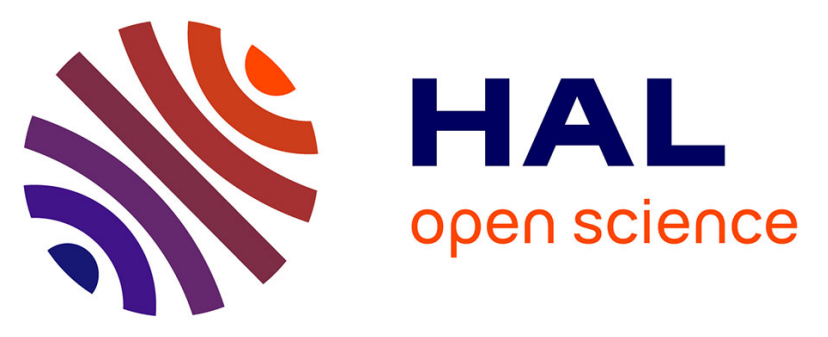

\title{
Improved Deschampsia cespitosa growth by nitrogen fertilization jeopardizes Quercus petraea regeneration through intensification of competition
}

Antoine Vernay, Philippe Malagoli, Marine Fernandez, Thomas Perot, Thierry

Ameglio, Philippe Balandier

\section{To cite this version:}

Antoine Vernay, Philippe Malagoli, Marine Fernandez, Thomas Perot, Thierry Ameglio, et al.. Improved Deschampsia cespitosa growth by nitrogen fertilization jeopardizes Quercus petraea regeneration through intensification of competition. Basic and Applied Ecology, 2018, 31, pp.21-32. 10.1016/j.baae.2018.06.002 . hal-01893947

\section{HAL Id: hal-01893947 \\ https://hal.science/hal-01893947}

Submitted on 11 Oct 2018

HAL is a multi-disciplinary open access archive for the deposit and dissemination of scientific research documents, whether they are published or not. The documents may come from teaching and research institutions in France or abroad, or from public or private research centers.
L'archive ouverte pluridisciplinaire HAL, est destinée au dépôt et à la diffusion de documents scientifiques de niveau recherche, publiés ou non, émanant des établissements d'enseignement et de recherche français ou étrangers, des laboratoires publics ou privés.

\section{(1)(1) $\$(0)$}

Distributed under a Creative Commons Attribution - NonCommercial - ShareAlikel 4.0 
Dear author,

Please note that changes made in the online proofing system will be added to the article before publication but are not reflected in this PDF.

We also ask that this file not be used for submitting corrections. 
 \\ Basic and Applied Ecology}

www.elsevier.com/locate/baae

Improved Deschampsia cespitosa growth by nitrogen fertilization jeopardizes Quercus petraea regeneration through intensification of competition

\author{
Q1 Antoine Vernay ${ }^{\mathrm{a}}$, Philippe Malagoli ${ }^{\mathrm{a}, *}$, Marine Fernandez ${ }^{\mathrm{a}}$, Thomas Perot ${ }^{\mathrm{b}}$, \\ Thierry Améglio ${ }^{\mathrm{a}}$, Philippe Balandier ${ }^{\mathrm{b}}$ \\ ${ }^{a}$ Université Clermont Auvergne, INRA, PIAF, 63000 Clermont-Ferrand, France \\ ${ }^{\mathrm{b}}$ Irstea, Research Unit on Forest Ecosystems (EFNO), Domaine des Barres, 45290 Nogent-sur-Vernisson, France
}

Received 10 October 2017; accepted 17 June 2018

\begin{abstract}
Plant-plant interactions show differential responses to different combinations of available resources that has been underexplored.

The short-term functional response of Quercus petraea seedlings and Deschampsia cespitosa tufts grown alone or in mixture was monitored in contrasting combinations of soil inorganic nitrogen $\times$ light availabilities in a greenhouse experiment. Growth, biomass allocation, functional traits and resource acquisition were quantified. Intensity and importance of interactions were calculated by organ biomass-based indices.

Competition exerted by D. cespitosa on oak was primarily driven by light availability and secondly, for each light level, by nitrogen supply, leading to a strong hierarchy of resource combinations for each considered plant organ. Under high light, oak preferentially allocated biomass to the roots, underlining the indirect role of light on the belowground compartment. Unexpectedly, Deschampsia cespitosa grew better in the presence of oak seedlings under high nitrogen supply whatever the light availability.

Oak short-term nitrogen storage instead of investment in growth might be a long-term strategy to survive $D$. cespitosa competition. Why Deschampsia had a higher biomass in the presence of oak under nitrogen fertilization is an intriguing question. The role of root exudates or change in balance between intra- $v s$ interspecific interactions may hold the answer. There may be an active mechanism of competition rather than only competitive resource exploitation.

Forest managers sometimes practice adding nitrogen fertilizer to improve oak seedling growth in plantations or natural regeneration. Here, the higher biomass in mixture to the benefit of the competitor clearly questions this practice: oak may provide extra nitrogen to competitors during the early period of plant-plant interaction or it may influence the balance between intra- $v s$ interspecific interactions. The identification and quantification of active competition may result in new practices for a broad diversity of plant-plant interactions such as tree regeneration, intercrop management and weed control in agriculture.
\end{abstract}

(c) 2018 Published by Elsevier GmbH on behalf of Gesellschaft für Ökologie.

Keywords: Competition; Functional traits; Light; Plant interactions; Regeneration; Soil inorganic nitrogen; Intra/interspecific interactions

\footnotetext{
*Corresponding author.

E-mail address: philippe.malagoli@uca.fr (P. Malagoli).
} 


\section{Introduction}

Plant ability to compete for resources has long been studied over a wide range of species, but no unifying theory has yet emerged to explain all plant responses to biotic interactions in different abiotic contexts. Grime (1974) first proposed a three-determinant triangle-competition, stress, disturbance - to classify plant species on a site according to their behavior to cope with resource availability and stress/disturbances in a given environment. Based on his own observations, Grime concluded that competition grew stronger with higher soil fertility (Grime 1974). In another approach, Tilman (1987) focused on the processes involved in competition and suggested that competition was strongest for soil resources in an unfertile environment and strongest for light in a fertile environment. However, neither theory satisfactorily accounts for every observed plant response to the combined effects of competition and fluctuating resource availability (Craine 2005). Nevertheless, more recent studies have managed to reconcile these theories, as both would predict survival of the species with the lowest $\mathrm{R}^{*}$, i.e. the lowest resource level allowing the plant to survive, to the detriment of species with higher $\mathrm{R}^{*}$. The difference between the two theories resides in the intensity of the disturbances studied, i.e. a relatively low disturbance intensity for Tilman and higher intensity for Grime (Grime 2007; Jabot \& Pottier 2012). Plant growth and functional responses remain unclear in several cases of resource limitations. Pugnaire and Luque (2001), using an environmental gradient, showed stronger competition in the most fertile environment, as predicted by Grime, but they also found that belowground organs underwent stronger competition in the most stressful environment than in the most fertile one, thus endorsing Tilman's theory (Pugnaire \& Luque 2001). They demonstrated a dynamic balance between facilitation and competition along the environmental gradient. This is relevant to the facilitation process (broadly defined as at least positive impact of plant A on plant B) which is positively correlated to stress intensity (Bertness \& Callaway 1994) until facilitation collapses under the highest stress or until competition intensity overtakes facilitation intensity (Verwijmeren, Rietkerk, Wassen, \& Smit 2013). However, conclusions strongly depend on experimental design and/or environmental contexts.

Interactions can be characterized by two variables: importance and intensity (Welden \& Slauson 1986; Corcket, Liancourt, Callaway, \& Michalet 2003). Intensity is defined as the absolute effect of plant A on plant B, commonly measured by comparing a performance index such as plant biomass with or without a neighbor. Importance is defined as the relative negative impact of competition on plant fitness traits compared with environmental constraints (Welden \& Slauson 1986; Brooker et al. 2005). This concept of importance was introduced to assess the contribution of the interaction effect relative to the environment effect in reducing the performance of a given plant. How intensity and importance vary among different multi-resource availabilities is still largely unknown (Pugnaire \& Luque 2001; Liancourt, Corcket, \& Michalet 2005; Pugnaire, Zhang, Li, \& Luo 2015).

When several species are competing for the same resources, plants can also acclimate in response to new environmental conditions with fewer resources (Violle et al. 2007). According to a plant's phenotypic plasticity, plant traits can be adjusted to optimize the growth of organs involved in resource capture so as to better cope with competitive neighbors, and with greater efficiency (Casper \& Jackson 1997). This pattern is consistent with foraging theory, which states that when a resource is rare, capture organs can acclimate to become more efficient and favor higher growth. In contrast, in the conservative strategy, nutrients and carbohydrates are preferentially stored in perennial organs for later re-use in a more favorable environmental context, reducing risk of survival failure (Valladares, Martinez-Ferri, Balaguer, Perez-Corona, \& Manrique 2000; Yan, Wang, \& Huang 2006).

Most earlier studies on plant-plant interactions have only considered one resource. Very few studies have accounted for crossed availabilities in aerial and soil resources, including soil inorganic nitrogen $\left(\mathrm{N}_{\text {soil }}\right)$ (Davis et al. 1999; Siemann \& Rogers 2003), and most of them were designed incompletely for all of the factors combinations or with only partial control of factors studied. Here, we studied how light and nitrogen availability and their interactions could influence plant responses to biotic interactions in terms of growth and functional traits. These two factors would enable to separate aboveground competition from belowground competition in terms of importance and intensity of interaction.

Our experiment aimed to measure early plant responses of sessile oak (Quercus petraea) seedlings and Deschampsia cespitosa in a mixture, in terms of growth and resource acquisition in four nitrogen $\times$ light combinations. These two species are widespread and commonly occur in interaction throughout temperate European forests (Davy 1980). Current silvicultural practices that aim to reduce standing tree density (Puettmann et al. 2015) will increase light in the understory, thus favoring colonization by the herbaceous $D$. cespitosa. We expected to find a mitigated competition by grasses in a shaded environment associated with lower grass performance in terms of growth and functioning. We expected oak seedlings to show higher investment to the root compartment in unfertilized places (higher root biomass, specific root length (SRL), allocation of resources to the root system) and higher investment for aboveground organs in a shaded environment (higher growth rate, preferential allocation of resources to leaves). We expected to find that the underground foraging behavior of oak would counteract the fast $D$. cespitosa growth. The experimental setup was designed (i) to determine how growth of oak/D. cespitosa was affected by the combination of abiotic environments on a short-term scale and how functional traits allow both plants to acclimate or respond to resource combinations of resources in 
Monosculture

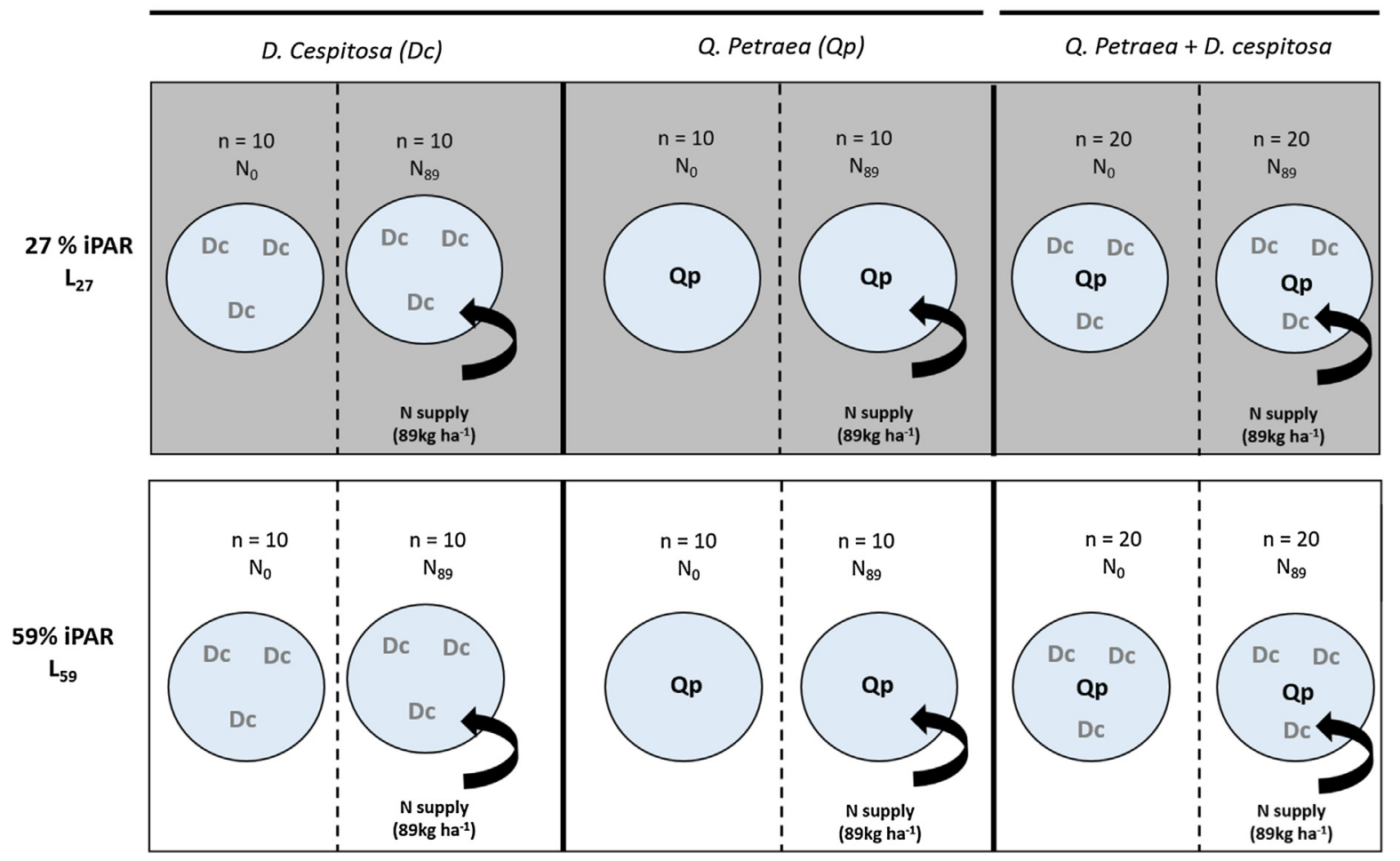

Fig. 1. Experimental design of all crossed treatment combinations. $\mathrm{Dc}=D$. cespitosa, $\mathrm{Qp}=$ Quercus petraea, $\mathrm{N}=$ nitrogen, $\mathrm{n}=$ number of replicates (see text for details).

terms of resource acquisition strategy, and (ii) to determine the importance and intensity of interactions (positive or negative), and (iii) to elucidate the plant response strategies employed to deal with these interactions in all the treatment combinations.

\section{Materials and methods}

\section{Experimental setup}

The experiment was conducted in a greenhouse at the INRA UMR PIAF research unit in Clermont-Ferrand (Auvergne, France, $45^{\circ} 45^{\prime} \mathrm{N} 3^{\circ} 07^{\prime} \mathrm{E}$, altitude $394 \mathrm{~m}$ a.s.l) from mid-December 2014 to June 2015. A total of 120 oneyear-old bare-root oak seedlings [Q. petraea (Matt.) Leibl.; $149 \pm 20 \mathrm{~g}$ fresh weight on average per tree] sourced from a local tree nursery were planted on December 15, 2014 in 20L pots filled with a local sandy-clay soil (clay $20.3 \%$, loam $22.8 \%$, sand $56.9 \%$; $\mathrm{pH} 6.15$, total $\mathrm{N}$ content $1.45 \mathrm{~g} \mathrm{~kg}^{-1}$, total C content $14.6 \mathrm{~g} \mathrm{~kg}^{-1}$ ) before bud break. D. cespitosa (L.) tufts (aboveground parts + roots) were carefully collected under natural forest conditions at Paray-le-Frésil (Auvergne, France; $46^{\circ} 39^{\prime} \mathrm{N} 3^{\circ} 36^{\prime} \mathrm{E}$ ) and then transplanted into the pots on December 16, 2014. Oak seedlings were grown (i) without $D$. cespitosa [sole species; 40 pots (one seedling per pot)] or (ii) with three surrounding tufts [mixed species; 80 pots,
$0.97 \pm 0.02 \mathrm{~g}$ per fresh tuft matter of $D$. cespitosa], and the last treatment was (iii) D. cespitosa (3 tufts per pot) without oak seedlings (40 pots). Mixture density was set to be as close as possible to species abundance in real field conditions, in terms of relative abundance. Half of the pots were exposed to $59 \%$ of the photon flux density (PFD) in the photosynthetic active radiation range (PAR) reaching the top of the greenhouse (i.e. resulting from greenhouse structure interception), and mimicking an appreciable forest gap under in situ conditions, treatment $\mathrm{L}_{59}$. The other half was set under net shelters (Hormasem ${ }^{\circledR}, 50 \%$ extinction), exposing pots to $27 \%$ of the PFD measured above the greenhouse i.e. close to \%PFD values frequently recorded under an open natural oak canopy, treatment $\mathrm{L}_{27}$ (Fig. 1). Our net shelters gave sun protection with no influence on the red-to-far-red ratio of the PFD, so light quality was the same outside and under net shelters. Finally, for the two irradiances, half the pots were supplied with either added $\mathrm{NH}_{4} \mathrm{NO}_{3}$ solution corresponding to a fertilization rate of $89 \mathrm{~kg} \mathrm{ha}^{-1} \mathrm{year}^{-1}$ (924 mg of inorganic N Q3 per pot or $0.42 \mathrm{~g} \mathrm{~kg}^{-1}$, treatment $\mathrm{N}_{89}$ ) or no $\mathrm{NH}_{4} \mathrm{NO}_{3}$ addition, treatment $\mathrm{N}_{0}$. For $\mathrm{N}_{89}$, fertilization was applied three times at an average rate of $26 \mathrm{~kg} \mathrm{~N} \mathrm{ha}^{-1}$ year $^{-1}\left(0.14 \mathrm{~g} \mathrm{~kg}^{-1}\right)$ in March, April and May, evenly spread with a bottle on the pot surface. $\mathrm{N}_{0}$ corresponded to native $\mathrm{N}_{\text {soil }}$ (Fig. 1). Light treatment was constant over the growth period (December 2014-June 2015) whereas fertilization was applied in three pulses. Because no statistical effect of single fertilization 
pulses was recorded on the growth curves (data not shown), the data collected at the end of the experiment were interpreted from an integrated response over all the period. Mean temperature over the experiment was $21 \pm 4^{\circ} \mathrm{C}( \pm \mathrm{SD}$; min. $14^{\circ} \mathrm{C}$, max. $30^{\circ} \mathrm{C}$ ). Mean air humidity over the experiment was $63 \pm 8 \%( \pm \mathrm{SD}$; min. $42 \%$, max. $82 \%)$. Any undesirable species appearing in pots were manually weeded out. Forty pallets (considered here as subplots) gathered six pots for technical convenience, with 15 subplots shaded. All other treatments ( $\mathrm{N}$ and biotic interactions) were randomly distributed among subplots, in equal numbers in each light treatment.

\section{Growth measurement}

Height of oak seedlings, highest $D$. cespitosa leaf, and diameter at the stem base of oak seedlings were measured every 10 days throughout the experiment. Relative growth rate (RGR) was calculated for diameter and height with the formula:

$\mathrm{RGR}=\frac{\ln \left(x_{t_{2}}\right)-\ln \left(x_{t_{1}}\right)}{t_{2}-t_{1}}$

where $x$ is plant height or diameter, $t_{2}$ is date of harvest, and $t_{1}$ is date of planting.

\section{${ }^{15} \mathrm{~N}$ labeling}

${ }^{15} \mathrm{NO}_{3}{ }^{15} \mathrm{NH}_{4}\left(20 \mathrm{mg}\right.$ of ${ }^{15} \mathrm{~N}$ dissolved in $500 \mathrm{~mL}$ of water) was evenly supplied at the surface of each pot on June 05 , 2015 to assess how $\mathrm{N}$ uptake during the vegetative season was distributed between and within each species. Total $\mathrm{N}$ content and ${ }^{15} \mathrm{~N}$ isotopic abundance were determined by isotope-ratio mass spectrometry at the PTEF OC 081 (Nancy) functional ecology platform. Labeling methods and associated calculations are detailed in Vernay, Balandier, Guinard, Améglio, and Malagoli (2016).

\section{Plant harvesting}

Plants were harvested on June 22, 2015. Aboveground parts and roots were collected in both species. For oak, aboveground parts were separated into woody parts and leaves and dried at $60^{\circ} \mathrm{C}$ for at least $48 \mathrm{~h}$ before dry weight determination, and roots were separated into fine (diameter $<2 \mathrm{~mm}$ ) and coarse (including taproot, diameter $>2 \mathrm{~mm}$ ). For D. cespitosa, no diameter distinction was made (diameter always $<2 \mathrm{~mm}$ ). Soil and stones left around the root were then washed out with tap water. A sub-sample of roots (one per species) for each harvested pot was collected, wrapped in moist paper, and stored at $-20^{\circ} \mathrm{C}$ for morphological analysis. The remaining part was dried at $60^{\circ} \mathrm{C}$ for at least $48 \mathrm{~h}$ before dry weight determination.

\section{Root trait measurements}

Frozen sub-samples of fine roots were thawed and scanned (Epson scanner, professional mode, 16 bits, dpi 600, pictures in TIF format). D. cespitosa roots were pre-colored with methylene blue to improve contrasts. Pictures were then analyzed with WinRHIZO ${ }^{\circledR}$ software (V2005a, Regent Instruments, Canada) to measure root length, surface and diameter. Specific root length (SRL) was expressed in $\mathrm{cm} \mathrm{g}^{-1}$.

\section{Intensity and importance of competition: calculation of indices}

Intensity and importance of competition were assessed for both species using two indices, i.e. $I_{\text {int }}$ and $I_{\text {imp }}$, where $I$ for index refers to the neighborhood effect (Díaz-Sierra, Verwijmeren, Rietkerk, de Dios, \& Baudena 2016). We chose these indices as they are standardized and symmetrical, with finite limits, and thus allow unbiased comparisons. Calculations were done as follows:

$I_{\text {int }}=2 \times \frac{\Delta P}{P_{-\mathrm{N}}+|\Delta P|}$

$I_{\mathrm{imp}}=2 \times \frac{\Delta P}{2 \mathrm{MP}_{-\mathrm{N}}-P_{-\mathrm{N}}+|\Delta P|}$

where $P_{-\mathrm{N}}$ is plant performance without neighbor, $\Delta P$ is the difference between plant performance with and without neighbor, and $\mathrm{MP}_{-\mathrm{N}}$ is maximum plant performance among all treatment combinations $\left(\mathrm{MP}_{-\mathrm{N}}\right.$ was reached in $\mathrm{L}_{59} / \mathrm{N}_{89}$ for aboveground organs and in $\mathrm{L}_{59} / \mathrm{N}_{0}$ for belowground organs). Indices were calculated for each organ with dry biomass as the performance variable. Values of $I_{\text {int }}$ and $I_{\text {imp }}$ range between -1 and +2 and between -1 and $+2 / 3$, respectively. A negative or positive value means a competitive or a facilitative interaction, respectively.

\section{Statistics}

To analyze the effects of light intensity, nitrogen availability and biotic interactions on plant growth, we performed analyses of variance with linear mixed effects models. All analyzed data were based on the variables measured at harvest at the end of this experiment, i.e. in June 2015, and thus quantified integrated plant responses from December 2014 to June 2015.

All factors and factor-factor interactions were included in the model simultaneously. Full models were simplified by removing insignificant higher-order interactions. To account for the spatial structure of our experimental design, we introduced a subplot random effect in the models. Final models were fitted using the restricted maximum likelihood method (REML) to better estimate variance components (Pinheiro \& Bates 2000). The lme function of the nlme package (R 
Table 1. Model of nitrogen, light and biotic interaction for aboveground biomass for oak seedlings (leaves and stem) and D. cepsitosa (shoots). Only results from significant terms are shown. $\mathrm{Df}=$ degree of freedom (Num = numerator and Den = denominator), $\mathrm{N}=$ number of replicates, $\mathrm{N}=$ nitrogen, $\mathrm{L}=$ light, $\mathrm{BI}=$ biotic interaction, $\mathrm{DW}=$ dry weight, $\mathrm{SRL}=$ specific root length.

\begin{tabular}{|c|c|c|c|c|c|c|c|c|c|c|}
\hline & \multicolumn{5}{|c|}{ Oak seedlings } & \multicolumn{5}{|c|}{ D. cespitosa } \\
\hline & $\mathrm{N}$ & NumDf & DenDf & F-values & p-Values & $\mathrm{N}$ & NumDf & DenDf & F-values & p-Value \\
\hline Light & 119 & 1 & 36 & 15.3 & $<0.001$ & 119 & 1 & 38 & 64.5 & $<0.001$ \\
\hline Nitrogen & 119 & 1 & 75 & 9.9 & 0.002 & 119 & 1 & 74 & 145.9 & $<0.001$ \\
\hline Biotic interaction & 119 & 1 & 75 & 104.2 & $<0.001$ & & & & & \\
\hline $\mathrm{L} \times \mathrm{BI}$ & 119 & 1 & 75 & 21.9 & $<0.001$ & & & & & \\
\hline $\mathrm{N} \times \mathrm{BI}$ & 119 & 1 & 75 & 11.5 & 0.001 & 7 & & & & \\
\hline
\end{tabular}
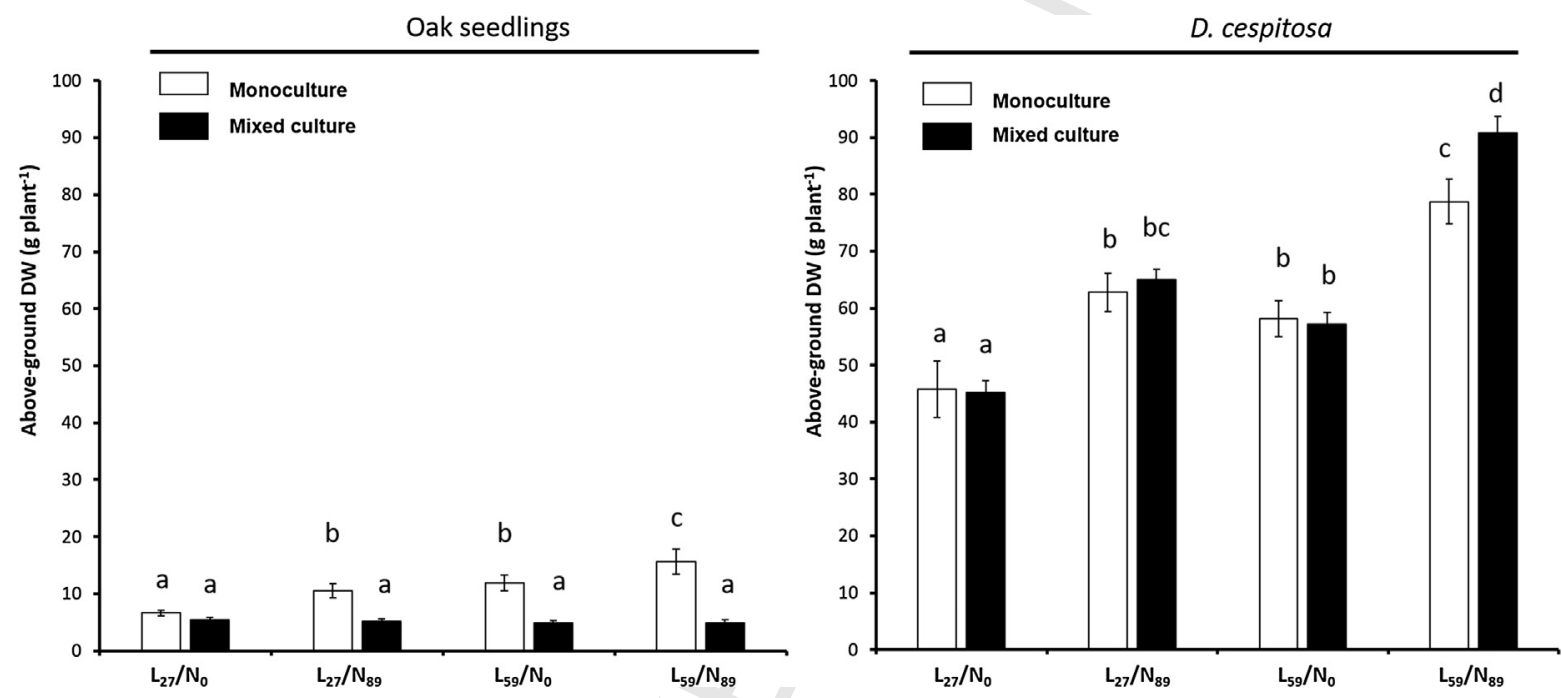

Fig. 2. Aboveground dry weight in sole-grown and mixed-grown oak and D. cespitosa under a crossed combination of two levels of light ( $\mathrm{L}_{59}$ and $\mathrm{L}_{27}$ ) and $\mathrm{N}_{\text {soil }}$ availability $\left(\mathrm{N}_{89}\right.$ and $\mathrm{N}_{0}$; see Materials and methods for further details). Values are reported as means $\pm \mathrm{SE}(n=10$ for sole-grown (SSp), $n=20$ for mixed-grown plants $(\mathrm{MSp})$, degree of freedom $=50)$. For statistical relevance, data were $\log _{10}$-transformed, but for readability, untransformed values are given in the figure. Different letters result from multiple pairwise comparisons (Tukey's HSD test) between each treatment combination at $p<0.05$.

software) was used to fit the linear mixed effect models (Pinheiro, Bates, DebRoy, \& Sarkar 2016). The conditional F-test given by the anova function of the nlme package was used to assess the significance of the different terms of the models. To determine which treatments differed from each other, we conducted multiple pairwise comparisons (Tukey's HSD test) using the lsmeans package (Lenth 2016). Because three-way interactions were never significant, we did not present them in our data. Comparison of ${ }^{15} \mathrm{~N}$ allocation (\%) between sole-grown species and mixed-grown species was assessed with a Student's t-test in each plant compartment.

RGR was measured via regular growth measurements enabling pot to also be included as a random factor for these variables. Preliminary analysis showed no effect of spatial position of each pot in the greenhouse. Some variables were transformed by a $\log _{10}$ function to meet normality and homoscedasticity requirements.

All analyses were conducted with the R software version 3.3.2 (R Core Team 2016).

\section{Results}

\section{Plant responses to biotic interactions under different resource combinations}

Only $\mathrm{N} \times$ biotic interactions and $\mathrm{L} \times$ biotic interactions had significant effects on aboveground oak seedling dry weight (leaf dry weight and stem dry weight, Table 1). Our data showed disordinal interactions (Doove, Van Buuren, \& Dusseldorp 2014), making simple factor interpretation irrelevant between sole and mixed grown oaks. Withoutneighbor data clearly showed a higher aboveground oak biomass when light and/or nitrogen were highly available (Fig. 2). $\mathrm{L}_{59} / \mathrm{N}_{89}$ produced significantly higher aboveground biomass than other treatment combinations. These positive effects were cancelled in mixed cultures, producing significant interactions between $\mathrm{L} \times$ biotic interaction and $\mathrm{N} \times$ biotic interaction (Fig. 2, Table 1). This pattern was observed for most of the oak variables studied (Appendix A in Supplementary material) except for whole plant biomass 
$\begin{array}{ll}\bigcirc & L_{59} / N_{0} \\ \triangle & L_{59} / N_{89} \\ \square & L_{27} / N_{0} \\ \diamond & L_{27} / N_{89}\end{array}$

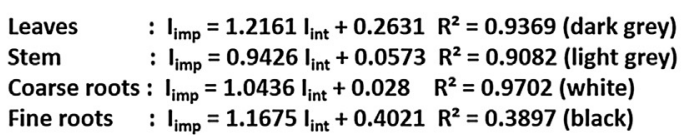

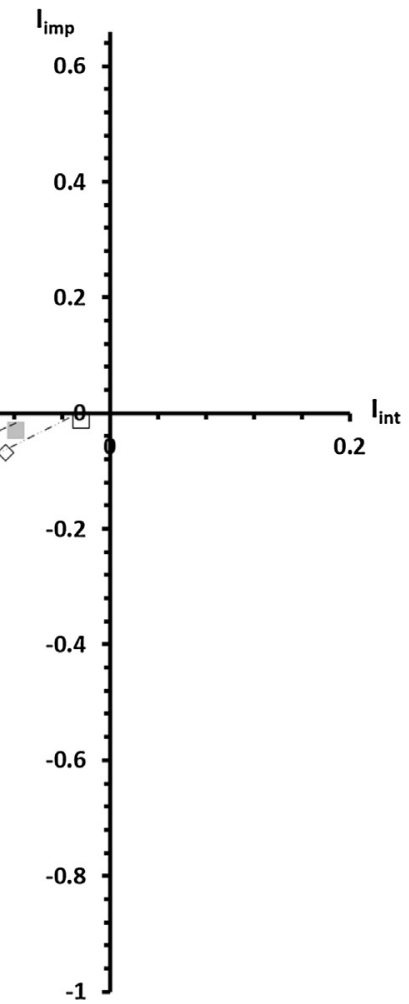

Fig. 3. Relationship between importance $\left(I_{\mathrm{imp}}\right)$ and intensity $\left(I_{\mathrm{int}}\right)$ of interaction between $D$. cespitosa and oak. Indices, based on oak biomass, were calculated for all crossed light $\times \mathrm{N}_{\text {soil }}$ availability combinations based on dry weight in fine roots (black-filled), coarse roots (white-filled), stem (light-grey-filled) and leaves (dark-grey-filled). Values are reported as means ( $n=10$ for monoculture, $n=20$ in mixtures). Regression equations and coefficients for each compartment are listed in the figure.

which was only dependent on biotic interactions and was not significantly sensitive to factor interactions (Appendix A in Supplementary material). Shoot/root, fine root area, leaf dry weight and total aboveground dry weight were all affected by $\mathrm{L} \times$ biotic interaction and $\mathrm{N} \times$ biotic interaction (Appendix $\mathrm{A}$ in Supplementary material), with lower values in MSp treatments than in SSp and no visible effect of L and N in MSp (data not shown). However, root length and stem dry weight were only sensitive to $\mathrm{L} \times$ biotic interaction (Appendix A in Supplementary material) whereas root diameter was only neagtively affected by $\mathrm{N} \times$ biotic interaction (Appendix $\mathrm{A}$ in Supplementary material).

Dry weights of fine and coarse roots in oak were not statistically different among all treatment combinations and were only dependent on the simple effects of light and/or biotic interaction (Appendix B in Supplementary material).

In contrast, aboveground biomass in mixed-grown $D$. cespitosa was unchanged compared with sole-grown $D$. cespitosa, except for $\mathrm{L}_{59} / \mathrm{N}_{89}$ where aboveground biomass was greater in the mixture (Fig. 2B). Aboveground biomass (mainly composed of leaves) was only affected by light and nitrogen availability, increasing aerial biomass, with no effect of interacting factors (Table 1). Only total plant dry weight was sensitive to factor interactions with the significant effect of $\mathrm{N} \times \mathrm{L}$ and $\mathrm{N} \times$ biotic interactions (Appendix A in Supplementary material). A positive effect of light was observed on root length, root diameter, root area, fine root dry weight, and biotic interactions influenced the SRL trait in D. cespitosa (Appendixes A and C in Supplementary material). In conclusion, D. cespitosa performance was mainly dependent on simple effects of each factor (except for total plant dry weight, Appendix A in Supplementary material) with little effect of biotic interaction whereas oak seedlings strongly suffered from biotic interaction cancelling all positive effects of higher $\mathrm{L}$ and $\mathrm{N}$ availability.

\section{Intensity $\left(I_{\text {int }}\right)$ and importance $\left(I_{\text {imp }}\right)$ of interaction with neighbor species}

Considering the effect of $D$. cespitosa on oak seedlings (Fig. 3), for every light $\times \mathrm{N}_{\text {soil }}$ combination, $I_{\text {int }}$ and $I_{\text {imp }}$ values were negative for all oak organs, indicating that the interaction was always competitive. $I_{\text {imp }}$ was highest (low competition) for $\mathrm{L}_{27} \times \mathrm{N}_{0}$ and lowest (high competition) for $\mathrm{L}_{59} \times \mathrm{N}_{89}$ (Fig. 3). Moreover, for a given N supply, both indices showed lower negative values in $\mathrm{L}_{59}$ than in $\mathrm{L}_{27}$. Within each $L$ treatment, index values were more negative in $\mathrm{N}_{89}$ than in $\mathrm{N}_{0}$ (Fig. 3). This pattern was observed for each organ, pointing to a common impact of D. cespitosa on the whole oak plant. Considering each oak organ, respectively, in aboveground and belowground compartments $\left(\mathrm{MP}_{-\mathrm{N}}\right.$ value was not the same according to aerial or belowground organs, 


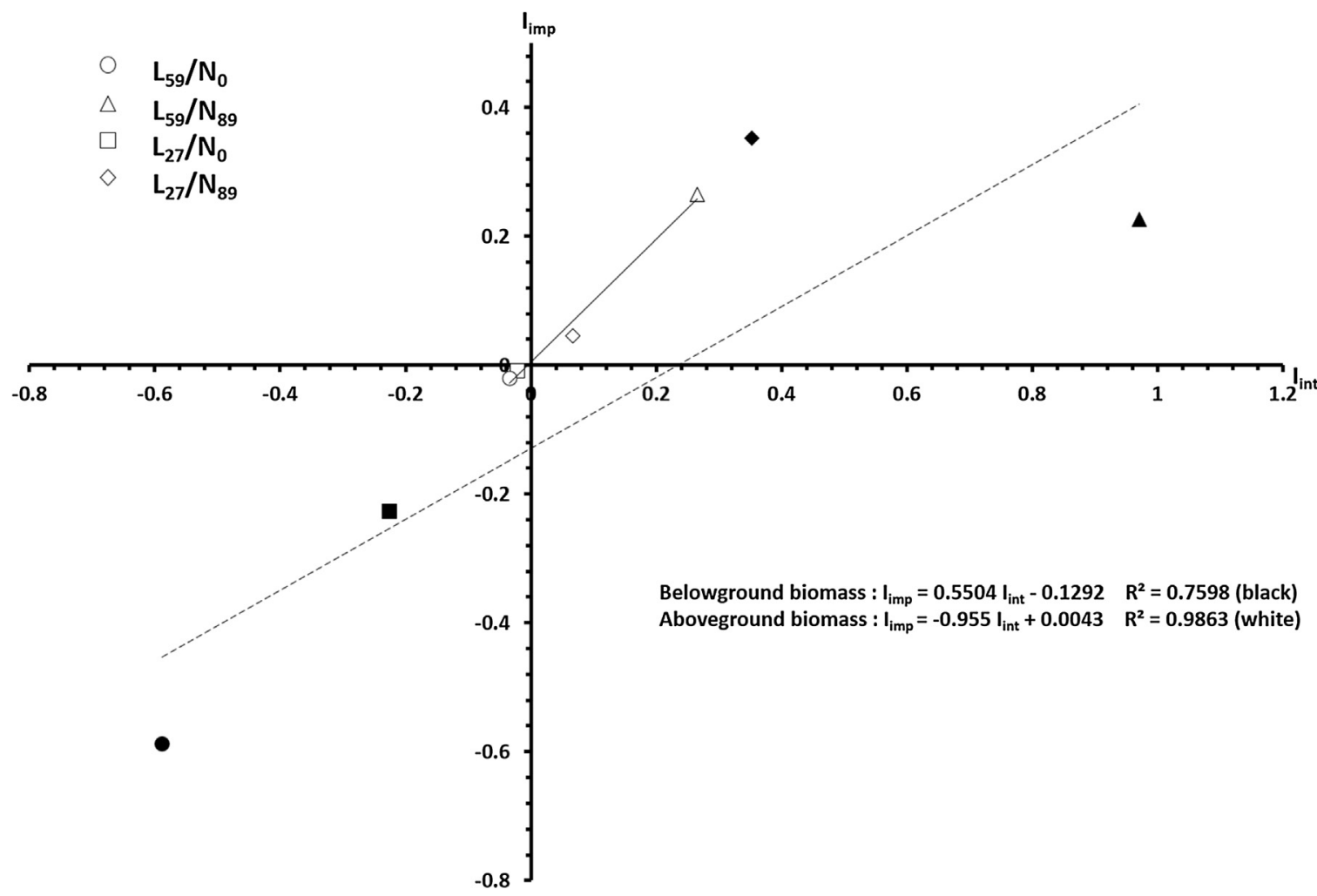

Fig. 4. Relationship between importance $\left(I_{\text {imp }}\right)$ and intensity $\left(I_{\text {int }}\right)$ of interaction between oak and D. cespitosa. Indices, based on $D$. cespitosa biomass, were calculated for all crossed light $\times \mathrm{N}_{\text {soil }}$ availability combinations based on dry weight in aboveground (white-filled) and belowground (black-filled) compartments. Values are reported as means ( $n=10$ for monoculture, $n=19$ in mixtures). Regression equations and coefficients for each compartment are listed in the figure.

hindering comparison), leaves and fine roots had more negative values for both indices than, in order, stem and coarse root (except for $\mathrm{L}_{27} \times \mathrm{N}_{89}$, where indices were lower in stem than in leaves). These results show that competition was stronger in capture organs (i.e. leaves and fine roots) than storage organs (i.e. stem and coarse roots).

The positive effect of oak on D. cespitosa, in $\mathrm{L}_{59} \times \mathrm{N}_{89}$ treatment, suggest two types of interaction: antagonistic facilitation under $\mathrm{N}_{89}$ (positive indices for D. cespitosa but negative indices for oak seedlings) and competition under $\mathrm{N}_{0}$ (negative indices, Fig. 4). The amplitude of the effect was much greater for belowground organs (very positive in $\mathrm{N}_{89}$ and very negative in $\mathrm{N}_{0}$ ) than aerial organs (close to zero, meaning a neutral interaction, Fig. 4).

\section{Nitrate and ammonium amounts in soil at harvest}

At the beginning of the experiment, amounts of nitrate and ammonium measured in pots were $0.032 \mathrm{~g} \mathrm{~kg}^{-1}$ and $0.0013 \mathrm{~g} \mathrm{~kg}^{-1}$, respectively. After 6 months of growth, there were much larger amounts of soil nitrate left in pots with sole-grown oak than in pots with either sole-grown D. cespitosa tufts or the mixture (Fig. 5). Amounts of soil ammonium showed no statistical difference according to mixture design or light $\times \mathrm{N}_{\text {soil }}$ combination (Fig. 5).

\section{Intra- and inter-specific allocation of soil inorganic ${ }^{15} \mathrm{~N}$}

Of $20 \mathrm{mg}$ of ${ }^{15} \mathrm{~N}$ applied per pot $7 \mathrm{mg} \pm 0.32 \mathrm{mg}(n=238)$ was taken up by the mixture of which $98 \%$ was allocated to $D$. cespitosa. In sole-grown oak seedlings, ${ }^{15} \mathrm{~N}$ was preferentially allocated to leaves (Fig. 6). In contrast, when mixed-grown with $D$. cespitosa, the ${ }^{15} \mathrm{~N}$ allocation pattern changed: ${ }^{15} \mathrm{~N}$ allocation to oak leaves was lowered to the benefit of coarse and fine roots (Fig. 6), with no change in the stem, which was not simply due to differences in biomass growth (Appendix B in Supplementary material). In sole-grown and mixed-grown $D$. cespitosa tufts, ${ }^{15} \mathrm{~N}$ was mainly allocated to aboveground parts (Fig. 6). This difference was not due to biomass difference. Allocation to the aboveground parts was higher in the mixture, at the expense of belowground parts.

\section{Discussion}

\section{Do light $\times$ soil inorganic $\mathbf{N}$ modulate plant interactions?}

Overall, increased availability in at least one of the two combined resources ( $\mathrm{L}$ and/or $\mathrm{N}_{\text {soil }}$ ) led to a reduced 


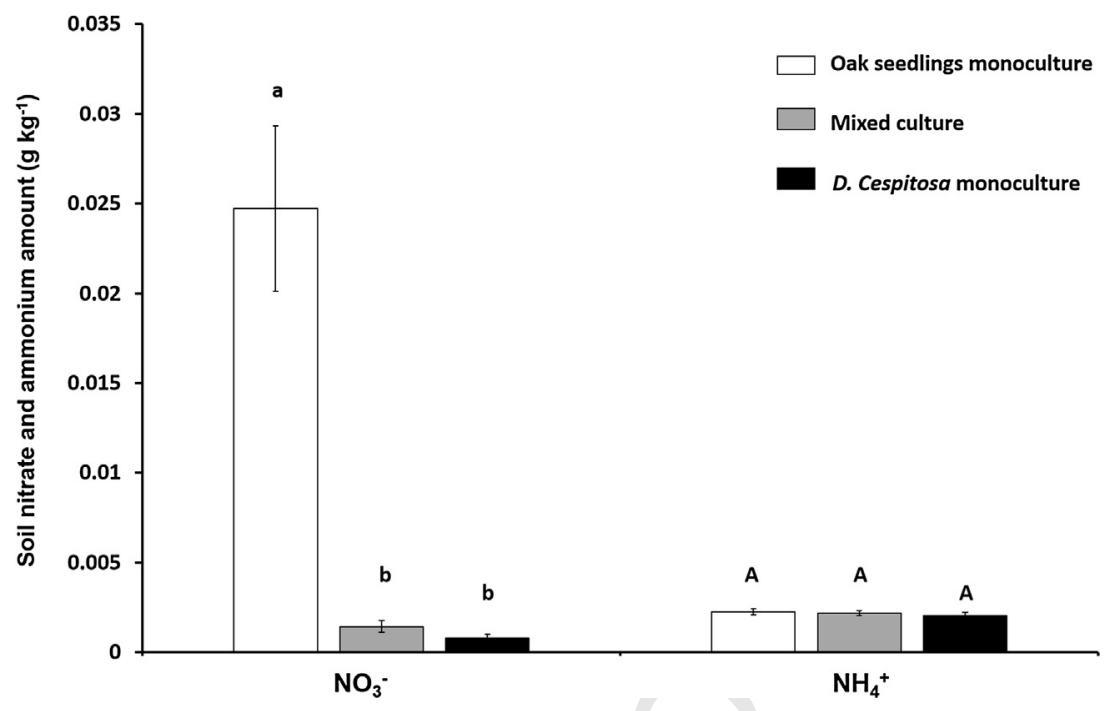

Fig. 5. Soil nitrate $\left(\mathrm{NO}_{3}^{-}\right)$and ammonium $\left(\mathrm{NH}^{+}\right)$contents $\left(\mathrm{g} \mathrm{kg}^{-1}\right)$ at harvest in sole-grown oak (white bars) and D. cespitosa (black bars) or in mixtures (grey bars) under all crossed light $\times \mathrm{N}_{\text {soil }}$ combinations. Values are reported as means $\pm \mathrm{SE}$ ( $n=3$ for monoculture, $n=6$ for mixtures, degrees of freedom $=27$ ). Different letters correspond to statistically significant differences between sole-grown plants and mixed-grown plants at $p<0.05$, after multiple pairwise comparisons (Tukey's HSD test).

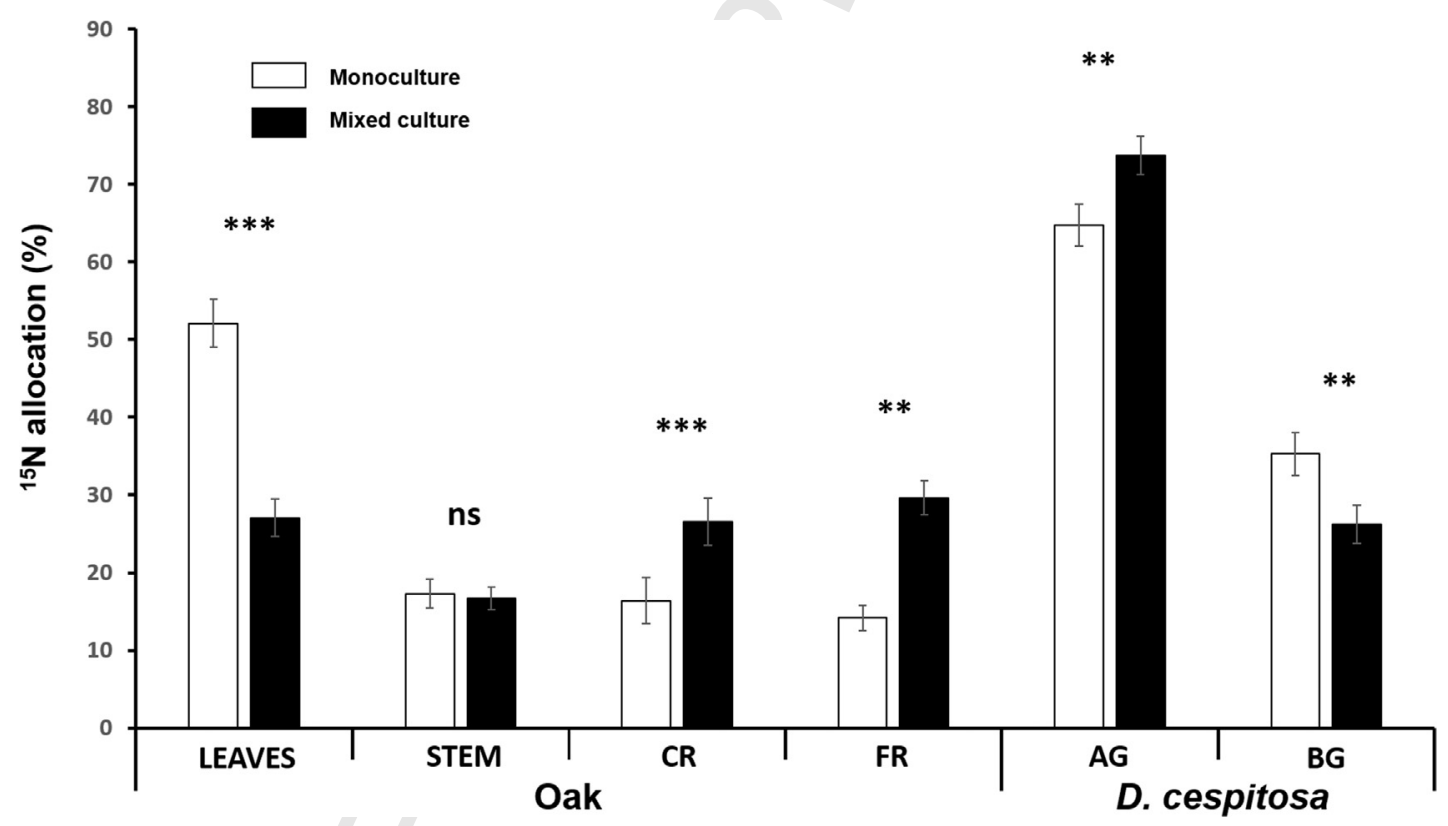

Fig. 6. Relative allocation of ${ }^{15} \mathrm{~N}$ among leaves, stems, coarse roots (CR) and fine roots (FR) in oak seedlings and $D$. cespitosa among aboveground (AG) and belowground (BG) plant parts in D. cespitosa when sole-grown (SSp) or mixed-grown (MSp). Values are reported as means \pm SE. ., ${ }^{*} * * * * *$ correspond to $p<0.1,0.05,0.01$ and 0.001 , respectively, after Student's $t$-test for each organ; degrees of freedom $=27$.

aboveground biomass in mixed-grown oak seedlings when compared to the low levels of the resources studied.

Deciphering combined effects of light and soil $\mathrm{N}$ on mixed-grown oak seedlings is not straightforward. Actually, neighbor-effect indices demonstrated a prevalence of light impact. First, the size difference (in favor of the taller oak seedlings) makes direct competition for light unlikely under our study set-up. Second, for a given amount of light, adding the $\mathrm{N}_{\text {soil }}$ resource increased both the intensity and importance of competition on oak. This would suggest that greater light availability may lead to higher carbon gain by $D$. cespitosa (Vernay et al. 2016). This extra amount of carbon would indirectly promote root system growth and thus pre-emption of $\mathrm{N}_{\text {soil }}$. The strong ability of D. cespitosa to capture $\mathrm{N}_{\text {soil }}$ led to a subsequent bypass of extra available resources to the detriment of oak growth (Freschet et al. 2017). This ability would explain the disordinal interaction observed (Doove et al. 2014). Actually, only sole-grown oaks significantly responded to additional resource amount. Indeed, some studies have reported that belowground resources play a key role 
in driving the competition relationship: in fertile soil, competitive exclusion occurs, enhanced by higher biomass allocation to aboveground organs, switching competition from nutrients to light (Newman 1973; Hautier, Niklaus, \& Hector 2009; DeMalach \& Kadmon 2017). However, these conclusions mainly result from studies on grassland communities, which share very similar ecological strategies. Here, perennials and ligneous species behaved differently and responded to different needs, which could explain why light would have a stronger influence. However, the two resources did not act independently (Rajaniemi 2002), as highlighted by neighboreffect indices. Taking into account crossed combinations of $\mathrm{N}_{\text {soil }} \times \mathrm{L}$ thus brings fine-tuning elements that have seldom been investigated together (but see Pugnaire \& Luque 2001).

The only situation when $D$. cespitosa had no effect on oak growth and associated traits was under low levels of both resources (i.e. $\mathrm{L}_{27}$ and $\mathrm{N}_{0}$ ). This is consistent with common findings in the literature (Baribault \& Kobe 2011; Vernay et al. 2016) reporting weaker competition under low light and nutrient availability, as competitive species free up their space for stress-tolerant species (Grime 1974; Pierret et al. 2016).

\section{How to explain the positive effect of oak seedling on $D$. cespitosa biomass?}

Antagonistic facilitation (i.e. when species A has a positive effect on species B but B a negative effect on A) of D. cespitosa by oak seedlings, in the $\mathrm{N}_{89}$ treatments whatever the light level, was an unexpected and surprising finding (Stachowicz 2001; Schöb, Prieto, Armas, \& Pugnaire 2014).

Two processes may be proposed to explain this positive effect on $D$. cespitosa. First, oak seedlings could have a higher rhizodeposition in fertilized pots without any biomass change (Karst, Gaster, Wiley, \& Landhausser 2016). This supplementary nitrogen supply might offer an extra soil $\mathrm{N}$ source, rapidly absorbed by $D$. cespitosa. As a perspective, identifying and then quantifying such fluxes would be hugely informative to help gain a refined understanding of the underlying mechanisms. Second, interspecific competition could be amplified in $\mathrm{N}_{89} / \mathrm{L}_{59}$, becoming stronger than intraspecific grass competition (Vernay et al. 2018). This process could be fostered by exudates which would act as signals in the rhizosphere, allowing self-recognition in a plant community (Delory, Delaplace, Fauconnier, \& du Jardin 2016). Exudates coming from other species may trigger positive feedback on root length and root density of D. cespitosa (Semchenko, Saar, \& Lepik 2014).

\section{$\mathbf{N}_{\text {soil }}$ depletion to the benefit of $D$. cespitosa}

More than $90 \%$ of ${ }^{15} \mathrm{~N}$ applied was massively absorbed by D. cespitosa tufts, in line with previous studies (Coll, Balandier, \& Picon-Cochard 2004; Vernay et al. 2016).
According to Tilman's theory, this would suggest that the competitive relationship was due to a low $R^{*}$ of $D$. cespitosa, i.e. a high growth potential at very low levels of resources (Tilman 1982). Such behavior raises questions over the sustainability of the grass's life cycle. On the one hand, it is legitimate to question whether the strategy of $D$. cespitosa involves a continuous depletion of resources at the risk of not being able to maintain the whole organism later on due to excessive growth (Hardin 1968; Gersani, Brown, O’Brien, Maina, \& Abramsky 2001). On the other hand, "game theory" (trade-off between survival at the community level and growth at the plant level) would predict a trade-off between resource depletion for individual $D$. cespitosa growth and the cost of individual maintenance induced by its growth (McNickle \& Dybzinski 2013).

\section{In planta ${ }^{15} \mathrm{~N}$ allocation: a conservative strategy for oak}

Oak seedlings in the mixture allocated much more ${ }^{15} \mathrm{~N}$ to coarse and fine roots to the detriment of leaves than solegrown seedlings. This phenomenon was observed in a very short time (only 6 months of interaction) which has rarely been quantified in literature. Indeed, this study shows that plant-plant interactions and their responses in terms of life strategy occur very rapidly. We suggest that higher oak N allocation to belowground compartments may feed an $\mathrm{N}$ storage pool (Vizoso et al. 2008) instead of using it for prospection and resource capture, associated with low investment in tissue creation (fine root dry weight was constant despite $\mathrm{N}$ allocation change). Oak strategy is therefore conservative.

Nitrogen resource can be taken up and assimilated quickly (Uscola, Villar-Salvador, Oliet, \& Warren 2014; Gao, Chen, Yuan, Zhang, \& Mi 2015). However, few studies have shown an early preferential $\mathrm{N}$ distribution to the root system, as has been done for carbon (Kaiser et al. 2015).

\section{Foster oak regeneration in practice}

Because the presence of oak had an unexpected positive effect on $D$. cespitosa growth when $\mathrm{N}$ fertilizer was added, field fertilization cannot be recommended (Coll et al. 2004; Salifu, Jacobs, \& Birge 2009). Use of preliminary N-loaded oak seedlings coming from a nursery would allow oak to benefit from its own internal N-reserve, improving its survival and its resistance to grass-driven N-depletion (Salifu \& Timmer 2001; Villar-Salvador et al. 2012; Vernay et al. 2018). Another solution would be to consider foliar fertilization, allowing to target oak seedlings more specifically without fertilizing understory species (Gagnon \& Deblois 2014). All suggested solutions will not be efficient without grass management reducing grass density. This can be achieved by decreasing light availability when possible. 


\section{Conclusion}

As expected, D. cespitosa competed with oak seedlings and to the detriment of oak. This competition arose whenever resources became more available (59\% PFD for light and $89 \mathrm{~kg} \mathrm{ha}^{-1} \mathrm{~N}$ supply). This study shows original responses of plant-plant interactions in different resource combination (antagonistic facilitation of $D$. cespitosa by oak seedlings and indirect influence of light). This further argues for considering crossed factors instead of one resource. Neighbor-effect indices indicated that light was a primary factor driving plant response, but this effect was indirect as driven by improved $\mathrm{N}_{\text {soil }}$ uptake. Each species exhibited a contrasting response strategy to competition and $\mathrm{N}_{\text {soil }} \times$ light combinations: a conservative strategy for oak, and a capture strategy for $D$. cespitosa. Finally, D. cespitosa growth was enhanced by the presence of oak under high $\mathrm{N}_{\text {soil }}$.

Investigation of functional mechanisms of antagonistic facilitation and intra- $v s$ interspecific interaction balance offers interesting perspectives for further studies: $\mathrm{N}$ storage in oak might play a pivotal role in coping with $\mathrm{N}_{\text {soil }}$ depletion by $D$. cespitosa. Other soil resources, such as water or phosphorus, also warrant attention. Finally, it would be of great interest to test whether such observations also occur under natural conditions.

\section{Authors' contributions}

$\mathrm{AV}, \mathrm{PM}, \mathrm{TA}$ and $\mathrm{PB}$ conceived the ideas and designed the methodology; AV and MF collected the data; AV, TP, PM, TA and PB analyzed the data; AV, PM, TA and PB wrote the manuscript. All the authors contributed critically to the drafts and gave final approval for publication.

\section{Acknowledgments}

This work received financial support from the European Agricultural Fund for Rural Development (EAFRD 'Leader' programme), the French Ministry of Agriculture, the Auvergne Region Directorate for Agriculture (DRAAF), and the Allier department (CG 03). The authors thank André Marquier, Christophe Serre, Aline Faure, Patrice Chaleil, Brigitte Saint-Joanis, Marc Vandame, Pascal Walser and Pierre Conchon for their invaluable help in preparing the greenhouse setup, managing daily pot watering and shading, weekly measurements of plant growth, plant and soil harvesting, data collection and sample processing. We also thank Dr. Catherine Picon-Cochard for her expertise in running the WinRHIZO ${ }^{\circledast}$ software, and Dr. Pascale Maillard for expediently shipping the isotope. The authors thank the certified facility in functional ecology (PTEF OC 081) from UMR 1137 EEF and UR 1138 BEF at the INRA Nancy-Lorraine research center for its contribution to isotopic analysis. The PTEF facility is supported by the French National Research Agency through the ARBRE Laboratory of Excellence program (ANR-11-LABX-0002-01). Antoine Vernay was supported by a French Ministry of Research grant. Finally, the authors thank the three anonymous reviewers for their advice and comment.

\section{Appendix A. Supplementary data}

Supplementary data associated with this article can be found, in the online version, at https://doi.org/10.1016/ j.baae.2018.06.002.

\section{References}

Baribault, T. W., \& Kobe, R. K. (2011). Neighbour interactions strengthen with increased soil resources in a Northern hardwood forest. Journal of Ecology, 99(6), 1358-1372. http://dx.doi.org/ 10.1111/j.1365-2745.2011.01862.x

Bertness, M. D., \& Callaway, R. (1994). Positive interactions in communities. Trends in Ecology \& Evolution, 9(5), 191-193. http://dx.doi.org/10.1016/0169-5347(94)90088-4

Brooker, R., Kikvidze, Z., Pugnaire, F. I., Callaway, R. M., Choler, P., Lortie, C. J., \& Michalet, R. (2005). The importance of importance. Oikos, 109(1), 63-70. http://dx.doi.org/ 10.1111/j.0030-1299.2005.13557.x

Casper, B. B., \& Jackson, R. B. (1997). Plant competition underground. Annual Review of Ecology and Systematics, 28, 545-570. http://dx.doi.org/10.1146/annurev.ecolsys.28.1.545

Coll, L., Balandier, P., \& Picon-Cochard, C. (2004). Morphological and physiological responses of beech (Fagus sylvatica) seedlings to grass-induced belowground competition. Tree Physiology, 24(1), 45-54

Corcket, E., Liancourt, P., Callaway, R. M., \& Michalet, R. (2003). The relative importance of competition for two dominant grass species as affected by environmental manipulations in the field. Ecoscience, 10(2), 186-194.

Craine, J. M. (2005). Reconciling plant strategy theories of Grime and Tilman. Journal of Ecology, 93(6), 1041-1052. http://dx.doi.org/10.1111/j.1365-2745.2005.01043.x

Davis, M. A., Wrage, K. J., Reich, P. B., Tjoelker, M. G., Schaeffer, T., \& Muermann, C. (1999). Survival, growth, and photosynthesis of tree seedlings competing with herbaceous vegetation along a water-light-nitrogen gradient. Plant Ecology, 145, 341-350.

Davy, A. J. (1980). Deschampsia caespitosa (L.) Beauv. Journal of Ecology, 68(3), 1075-1096. http://dx.doi.org/10.2307/2259475

Delory, B. M., Delaplace, P., Fauconnier, M. L., \& du Jardin, P. (2016). Root-emitted volatile organic compounds: Can they mediate belowground plant-plant interactions? Plant and Soil, 402(1-2), 1-26. http://dx.doi.org/10.1007/s11104-016-2823-3

DeMalach, N., \& Kadmon, R. (2017). Light competition explains diversity decline better than niche dimensionality. Functional Ecology, 31(9), 1834-1838. http://dx.doi.org/ 10.1111/1365-2435.12841

Díaz-Sierra, R., Verwijmeren, M., Rietkerk, M., de Dios, V. R., \& Baudena, M. (2016). A new family of standardized and symmetric indices for measuring the intensity and importance of 
plant neighbour effects. Methods in Ecology and Evolution, 12 http://dx.doi.org/10.1111/2041-210x.12706

Doove, L. L., Van Buuren, S., \& Dusseldorp, E. (2014). Recursive partitioning for missing data imputation in the presence of interaction effects. Computational Statistics \& Data Analysis, 72, 92-104. http://dx.doi.org/10.1016/j.csda.2013.10.025

Freschet, G. T., Valverde-Barrantes, O. J., Tucker, C. M., Craine, J. M., McCormack, L. M., Violle, C., . . \& Roumet, C. (2017). Climate, soil and plant functional types as drivers of global fineroot trait variation. Journal of Ecology, n/a-n/a. http://dx.doi.org/ $10.1111 / 1365-2745.12769$

Gagnon, J., \& Deblois, J. (2014). . Effects of foliar urea fertilization on nitrogen status of containerized $2+0$ black spruce seedlings produced in forest nurseries (Vol. 57).

Gao, K., Chen, F., Yuan, L., Zhang, F., \& Mi, G. (2015). A comprehensive analysis of root morphological changes and nitrogen allocation in maize in response to low nitrogen stress. Plant, Cell \& Environment, 38(4), 740-750. http://dx.doi. org/10.1111/pce.12439

Gersani, M., Brown, J. S., O’Brien, E. E., Maina, G. M., \& Abramsky, Z. (2001). Tragedy of the commons as a result of root competition. Journal of Ecology, 89(4), 660-669. http://dx.doi.org/10.1046/j.0022-0477.2001.00609.x

Grime, J. P. (1974). Vegetation classification by reference to strategies. Nature, UK, 250(5461), 26-31.

Grime, J. P. (2007). Plant strategy theories: A comment on Craine (2005). Journal of Ecology, 95(2), 227-230. http://dx.doi.org/ 10.1111/j.1365-2745.2006.01163.x

Hardin, G. (1968). Tragedy of commons. Science, 162(3859), 1243.

Hautier, Y., Niklaus, P. A., \& Hector, A. (2009). Competition for light causes plant biodiversity loss after eutrophication. Science, 324(5927), 636-638.

Jabot, F., \& Pottier, J. (2012). A general modelling framework for resource-ratio and CSR theories of plant community dynamics. Journal of Ecology, 100(6), 1296-1302. http://dx.doi.org/ 10.1111/j.1365-2745.2012.02024.x

Kaiser, C., Kilburn, M. R., Clode, P. L., Fuchslueger, L., Koranda, M., Cliff, J. B., .. \& \& Murphy, D. V. (2015). Exploring the transfer of recent plant photosynthates to soil microbes: Mycorrhizal pathway vs direct root exudation. New Phytologist, 205(4), 1537-1551. http://dx.doi.org/10.1111/nph.13138

Karst, J., Gaster, J., Wiley, E., \& Landhausser, S. M. (2016). Stress differentially causes roots of tree seedlings to exude carbon. Tree Physiology, 11.

Lenth, R. V. (2016). Least-squares means: The R package lsmeans. Journal of Statistical Software, 69(1), 1-33.

Liancourt, P., Corcket, E., \& Michalet, R. (2005). Stress tolerance abilities and competitive responses in a watering and fertilization field experiment. Journal of Vegetation Science, 16(6), 713-722. http://dx.doi.org/10.1111/j.1654-1103.2005.tb02414.x

McNickle, G. G., \& Dybzinski, R. (2013). Game theory and plant ecology. Ecology Letters, 16(4), 545-555. http://dx.doi.org/ 10.1111/ele.12071

Newman, E. I. (1973). Competition and diversity in herbaceous vegetation. Nature, 244(5414), 310. http://dx.doi.org/ 10.1038/244310a0

Pierret, A., Maeght, J. L., Clement, C., Montoroi, J. P., Hartmann, C., \& Gonkhamdee, S. (2016). Understanding deep roots and their functions in ecosystems: An advocacy for more unconventional research. Annals of Botany, 118(4), 621-635. http://dx.doi.org/10.1093/aob/mcw130
Pinheiro, J., Bates, D., DebRoy, S., \& Sarkar, D. (2016). R Core Team (2016) nlme: Linear and Nonlinear Mixed Effects Models. R Package Version 3. 1-128. Available at https.Cran.r- Q8 702 Project.Org/Web/Packages/Nlme/Index.Html. (Accessed $7 \quad 703$ July).

Pinheiro, J. C., \& Bates, D. M. (2000). Theory and computational methods for linear mixed-effects models. In Mixed-effects models in $S$ and S-PLUS. pp. 57-96.

Puettmann, K. J., Wilson, S. M., Baker, S. C., Donoso, P. J., Drössler, L., Amente, G., ... \& Bauhus, J. (2015). Silvicultural alternatives to conventional even-aged forest management-What limits global adoption? Forest Ecosystems, 2, 8. http://dx.doi.org/ 10.1186/s40663-015-0031-X

Pugnaire, F. I., \& Luque, M. T. (2001). Changes in plant interactions along a gradient of environmental stress. Oikos, 93(1), 42-49. http://dx.doi.org/10.1034/j.1600-0706.2001.930104.x

Pugnaire, F. I., Zhang, L., Li, R. C., \& Luo, T. X. (2015). No evidence of facilitation collapse in the Tibetan plateau. Journal of Vegetation Science, 26(2), 233-242. http://dx.doi.org/ $10.1111 /$ jvs. 12233

R Core Team. (2016). R: A language and environment for statistical computing. Vienna, Austria: R Foundation for Statistical Computing. Retrieved from https://www.R-project.org/

Rajaniemi, T. K. (2002). Why does fertilization reduce plant species diversity? Testing three competition-based hypotheses. Journal of Ecology, 90(2), 316-324. http://dx.doi.org/ 10.1046/j.1365-2745.2001.00662.x

Salifu, K. F., Jacobs, D. F., \& Birge, Z. K. D. (2009). Nursery nitrogen loading improves field performance of bareroot oak seedlings planted on abandoned mine lands. Restoration Ecology, 17(3), 339-349. http://dx.doi.org/ 10.1111/j.1526-100X.2008.00373.x

Salifu, K. F., \& Timmer, V. R. (2001). Nutrient retranslocation response of Picea mariana seedlings to nitrogen supply. Soil Science Society of America Journal, 65(3), 905-913.

Schöb, C., Prieto, I., Armas, C., \& Pugnaire, F. I. (2014). Consequences of facilitation: One plant's benefit is another plant's cost. Functional Ecology, 28(2), 500-508. http://dx.doi.org/ 10.1111/1365-2435.12185

Semchenko, M., Saar, S., \& Lepik, A. (2014). Plant root exudates mediate neighbour recognition and trigger complex behavioural changes. New Phytologist, 204(3), 631-637. http://dx.doi.org/ 10.1111/nph.12930

Siemann, E., \& Rogers, W. E. (2003). Changes in light and nitrogen availability under pioneer trees may indirectly facilitate tree invasions of grasslands. Journal of Ecology, 91(6), 923-931. http://dx.doi.org/10.1046/j.1365-2745.2003.00822.x

Stachowicz, J. J. (2001). Mutualism, facilitation, and the structure of ecological communities. BioScience, 51(3), 235-246. http://dx. doi.org/10.1641/0006-3568(2001)051[0235:MFATSO2.0.CO;2]

Tilman, D. (1982). Resource competition and community structure. Princeton University Press.

Tilman, D. (1987). Secondary succession and the pattern of plant dominance along experimental nitrogen gradients. Ecological Monographs, 57(3), 189-214. http://dx.doi.org/10.2307/2937080

Uscola, M., Villar-Salvador, P., Oliet, J., \& Warren, C. R. (2014). Foliar absorption and root translocation of nitrogen from different chemical forms in seedlings of two Mediterranean trees. Environmental and Experimental Botany, 104, 34-43. http://dx.doi.org/10.1016/j.envexpbot.2014.03.004 
BAAE 51122 1-12

12

A. Vernay et al. / Basic and Applied Ecology xxx (2017) xxx-Xxx

761

763

764

765

766

767

768

769

770

771

772

773

774

775

776

777

778

779

780

781
Valladares, F., Martinez-Ferri, E., Balaguer, L., Perez-Corona, E., \& Manrique, E. (2000). Low leaf-level response to light and nutrients in Mediterranean evergreen oaks: A conservative resource-use strategy? New Phytologist, 148(1), 79-91. http://dx.doi.org/10.1046/j.1469-8137.2000.00737.x

Vernay, A., Balandier, P., Guinard, L., Améglio, T., \& Malagoli, P. (2016). Photosynthesis capacity of Quercus petraea (Matt.) saplings is affected by Molinia caerulea (L.) under high irradiance. Forest Ecology and Management, 376, 107-117. http://dx.doi.org/10.1016/j.foreco.2016.05.045

Vernay, A., Malagoli, P., Fernandez, M., Perot, T., Améglio, T., \& Balandier, P. (2018). Carry-over benefit of high internal $\mathrm{N}$ pool on growth and function of oak seedlings (Quercus petraea) competing with Deschampsia cespitosa. Forest Ecology and Management, 419-420, 130-138. http://dx.doi.org/10.1016/j.foreco.2018.03.039

Verwijmeren, M., Rietkerk, M., Wassen, M. J., \& Smit, C. (2013). Interspecific facilitation and critical transitions in arid ecosystems. Oikos, 122(3), 341-347. http://dx.doi.org/ 10.1111/j.1600-0706.2012.00111.x

Villar-Salvador, P., Puertolas, J., Cuesta, B., Penuelas, J. L., Uscola, M., Heredia-Guerrero, N., \& Benayas, J. M. R. (2012). Increase in size and nitrogen concentration enhances seedling survival in Mediterranean plantations. Insights from an ecophysiological conceptual model of plant survival. New Forests, 43(5-6), 755-770. http://dx.doi.org/10.1007/s11056-012-9328-6

Violle, C., Navas, M. L., Vile, D., Kazakou, E., Fortunel, C., Hummel, I., \& Garnier, E. (2007). Let the concept of trait be functional!. Oikos, 116(5), 882-892. http://dx.doi.org/ 10.1111/j.2007.0030-1299.15559.x

Vizoso, S., Gerant, D., Guehl, J. M., Joffre, R., Chalot, M., Gross, P., \& Maillard, P. (2008). Do elevation of $\mathrm{CO}_{2}$ concentration and nitrogen fertilization alter storage and remobilization of carbon and nitrogen in pedunculate oak saplings? Tree Physiology, 28(11), 1729-1739.

Welden, C. W., \& Slauson, W. L. (1986). The intensity of competition versus its importance-An overlooked distinction and some implications. Quarterly Review of Biology, 61(1), 23-44. http://dx.doi.org/10.1086/414724

Yan, E. R., Wang, X. H., \& Huang, J. J. (2006). Shifts in plant nutrient use strategies under secondary forest succession. Plant and Soil, 289(1-2), 187-197. http://dx.doi.org/ 10.1007/s11104-006-9128-x
782

783

784

785

786

787

788

789

790

791

792

793

794

795

796

797

798

799

800

801

802
803

Available online at www.sciencedirect.com

ScienceDirect

Please cite this article in press as: Vernay, A., et al. Improved Deschampsia cespitosa growth by nitrogen fertilization jeopardizes Quercus petraea regeneration through intensification of competition. Basic and Applied Ecology (2017), https://doi.org/10.1016/j.baae.2018.06.002 